\title{
KONTRIBUSI PEMANFAATAN PUPUK HAYATI DAN PUPUK KOMPOS TERHADAP PERTUMBUHAN DAN SERAPAN FOSFOR PADA TANAMAN JAGUNG
}

\section{Ernitha Panjaitan}

Fakultas Pertanian Universitas Methodist Indonesia, Medan- 20112

*Corresponding author : ernitha2005@yahoo.co.id

\section{ABSTRAK}

Jagung (Zea mays L.) merupakan salah satu tanaman pangan dunia yang terpenting, selain gandum dan padi. Lahan yang berpotensi sebagai lahan untuk produksi jagung diantaranya adalah lahan kering marginal. Lahan kering marginal adalah lahan yang tingkat kesuburannya rendah. Salah satu usaha yang dapat dilaksanakan untuk meningkatkan kesuburan tanah adalah melalui bioteknologi biofertiliser yaitu inokulasi mikoriza dan pemberian pupuk kompos. Penelitian dilakukan di lahan Fakultas Pertanian Universitas Metodist Indonesia. Percobaan menggunakan Rancangan Acak Kelompok (RAK) yang terdiri atas sembilan kombinasi perlakuan inokulasi mikoriza dan pupuk kompos dengan tiga ulangan. Perlakuan tersebut terdiri atas: $M_{0}$ (tanpa inokulan mikoriza); $M_{1}$ (inokulan $5 \mathrm{~g}$ tanaman $^{-1}$ ); $M_{2}$ (inokulan $10 \mathrm{~g}_{\text {tanaman }}{ }^{1}$ ) dan $\mathrm{O}_{0}$ (tanpa pupuk kompos); $\mathrm{O}_{1}$ (50 g pupuk kompos tanaman $\left.{ }^{-1}\right) ; \mathrm{O}_{2}$ (100 g pupuk kompos tanaman $\left.^{-1}\right)$. Hasil penelitian menunjukkan bahwa inokulasi mikoriza sebesar $10 \mathrm{~g}_{\text {tanaman }^{-1} \text { dan pupuk kompos sebesar } 100 \mathrm{~g} \text { tanaman }}$ ${ }^{1}$ memberikan kontribusi yang nyata terhadap pertumbuhan tanaman jagung meliputi tinggi tanaman dan diameter batang, sedangkan inokulasi mikoriza sebesar $10 \mathrm{~g}$ tanaman $^{-1}$ dan dosis pupuk kompos sebesar $50 \mathrm{~g}$ tanaman $^{-1}$ dapat meningkatkan serapan $P$ oleh tanaman jagung. Dengan demikian dapat disimpulkan bahwa kontribusi pemberian mikoriza dan pupuk kompos dapat meningkatkan kesuburan tanah lahan kering marginal ditandai dengan memacu pertumbuhan tanaman jagung dengan cara meningkatkan P-tersedia dan mengefektifkan penyerapan $P$ sehingga penggunaan pupuk $P$ dapat lebih efisien.

Kata kunci : mikoriza, pupuk kompos,pertumbuhan jagung, dan lahan kering marginal

\section{PENDAHULUAN}

Salah satu sumber bahan pangan pengganti beras yang mempunyai potensi yang baik adalah jagung. Agroindustri dengan bahan baku jagung saat ini sudah banyak beredar secara luas, seperti minyak jagung, sirup jagung dan gula jagung. Akan tetapi untuk aplikasi dimasyarakat teknologi tersebut sulit dilaksanakan karena memerlukan teknologi tinggi. Dalam kondisi produksi yang terus meningkat, harapan untuk menjadikan jagung sebagai bahan pangan nusantara cukup rasional, mengingat kandungan gizinya cukup tinggi. Namun, hingga saat ini minat masyarakat terhadap pangan berbasis jagung masih rendah. Hal ini disebabkan antara lain oleh kurangnya pengetahuan sebagian masyarakat tentang nilai gizi jagung, tampilan produk pangan dari jagung yang kurang menarik, dan adanya anggapan bahwa jagung hanya dikonsumsi oleh masyarakat berekonomi lemah. Oleh karena itu, perlu sosialisasi ke masyarakat, baik di perkotaan maupun pedesaan mulai dari informasi komposisi nutrisi, unsur pangan fungsional (nilai tambah) dan karakteristik fisikokimianya. Sebagai tanaman pangan yang mengandung manfaat untuk kesehatan, khasiat jagung antara lain sebagai 
pembangun otot dan tulang, baik untuk otak dan sistem syaraf, mencegah konstipasi, menurunkan risiko kanker dan jantung, mencegah gigi berlubang, serta minyaknya dapat menurunkan kolesterol darah. Ketersediaan makanan pokok bagi seluruh masyarakat dalam sebuah negara sangat berpengaruh terhadap kualitas SDM negara tersebut, sehingga pemenuhan kebutuhan akan makanan pokok menjadi penting. Subandi et al. (1998), menyebutkan bahwa kebutuhan akan pangan karbohidrat yang semakin meningkat akibat pertumbuhan penduduk sulit dipenuhi dengan hanya mengandalkan produksi padi, mengingat terbatasnya sumber daya terutama lahan dan irigasi. Sehingga dirasa perlu untuk meningkatkan produksi tanaman pengganti beras, yaitu jagung.

Salah satu usaha yang dapat dilaksanakan adalah peningkatan kesuburan tanah dengan pemberian pupuk yang mudah tersedia dan berkadar hara tinggi. Akan tetapi pemberian pupuk kimia atau anorganik untuk mempercepat proses peningkatan kesuburan tanah hanya akan meningkatkan kesuburan kimia tanah saja, sedangkan kesuburan fisik tanah akan tetap rendah dan bahkan kesuburan biologi tanah akan tertekan atau aktivitas mikroorganisme tanah yang membantu peningkatan kesuburan tanah akan terhenti dengan adanya pupuk kimia (anorganik) yang tinggi (Food and Fertilizer Technology Center, 2003 dalam Widyana, 2011).

Pemanfaatan pupuk organik semakin digalakkan karena berdampak positif baik bagi lingkungan maupun kesehatan masyarakat, karena tidak mengandung bahan-bahan kimia. Salah satu jenis pupuk organik yang sangat baik pengaruhnya bagi tanaman adalah yang berasal dari pembusukan sampah organik (kompos). Pupuk kompos mengandung unsur hara makro dan mikro, berfungsi meningkatkan kesuburan tanah, memperbaiki struktur tanah menjadi gembur, memperbaiki kehidupan jasad renik dalam tanah, meningkatkan ketersediaan asam organic dan zat bioaktif, meningkatkan responsibilitas unsur hara terhadap tanaman, meningkatkan $\mathrm{pH}$ tanah pada tanah masam,serta dapat meningkatkan kemampuan tanah untuk menahan air.

Selain pemanfaatan pupuk kompos, pupuk hayati juga banyak mendapat perhatian karena terbukti dapat meningkatkan kesuburan tanah (Kartini, 2000). Pupuk hayati adalah bahan penyubur tanah yang mengandung mikroorganisme yang berfungsi untuk meningkatkan ketersediaan unsur hara guna mendukung pertumbuhan tanaman. Salah satu mikroorganisme yang terdapat di dalam pupuk hayati adalah : jamur mikoriza. Mikoriza adalah merupakan suatu hubungan simbiosis mutualisme antara jamur yang dapat bersimbiosis antara jamur (mykes) dan akar (rhiza) tanaman tingkat tinggi (Sieverding, 1991). Hubungan simbiosis antara jamur mikoriza dan akar bersifat parasitisme yang tidak berbahaya tetapi memberikan keuntungan kepada tanaman inang, jamur mendapatkan karbohidrat dan energi dari tanaman, sedangkan tanaman mendapatkan unsur hara yang dibutuhkan untuk pertumbuhan (Bethlenfalvay, et al., 1982; 1991).

Atas dasar uraian-uraian tersebut diharapkan pemanfaatan pupuk kompos yang dikombinasikan dengan inokulan mikoriza dapat mengurangi ketergantungan terhadap pupuk anorganik dan sekaligus dapat mempertahankan dan meningkatkan pertumbuhan dan serapan $\mathrm{P}$ pada tanaman jagung, yang pada gilirannya dapat meningkatkan efisiensi pemupukan P. Penelitian ini bertujuan untuk mengetahui pengaruh aplikasi pupuk hayati dan pupuk kompos terhadap produksi dan serapan $\mathrm{P}$ pada tanaman jagung. 


\section{BAHAN DAN METODA}

Penelitian ini dilaksanakan di lahan milik Fakultas Pertanian UMI, Medan yang terletak di dengan ketinggian tempat $\pm 32 \mathrm{~m}$ di atas permukaan laut ( $\mathrm{dpl}$ ), yang dilaksanakan mulai bulan Juni sampai dengan September 2014. Adapun bahan yang digunakan dalam pelaksanaan penelitian adalah benih jagung varietas Hibrida-Pioneer, pupuk hayati mikoriza yang diperoleh dari Laboratorium Bioteknologi Hutan IPB Bogor, pupuk kompos, dan pupuk urea, SP-36, $\mathrm{KCl}$ sebagai pupuk dasar.

Alat yang digunakan dalam pelaksanaan penelitian adalah : cangkul, parang, tali plastik, garu, meteran, timbangan, jangka sorong, gembor, ember, penggaris dan alat tulis.

\section{Metode Penelitian}

Metode yang digunakan dalam penelitian ini adalah metode eksperimental dengan menggunakan Rancangan Acak Kelompok (RAK) dengan tiga ulangan. Adapun faktor- faktor perlakuan yang dicoba adalah sebagai berkut :

Faktor I : Pupuk hayati dengan inokulan mikoriza ( $\mathrm{M}) ; \mathbf{M}_{0}=$ tanpa inokulan mikoriza (kontrol), $\mathbf{M}_{1}=$ dengan inokulan mikoriza $5 \mathrm{~g} /$ tanaman, $\mathbf{M}_{2}=$ dengan inokulan mikoriza $10 \mathrm{~g} /$ tanaman. Faktor II; pupuk kompos $(\mathrm{O}), \mathrm{O}_{0}=$ tanpa pupuk kompos (kontrol), $\mathrm{O}_{1}=50 \mathrm{~g} /$ tanamam pupuk kompos, $\mathrm{O}_{2}=100 \mathrm{~g} /$ tanaman pupuk kompos. Berdasarkan kedua faktor perlakuan tersebut akan diperoleh 9 kombinasi perlakuan yang diulang sebanyak tiga kali sehingga terdapat 27 plot percobaan. Jumlah tanaman per plot sebanyak 4 tanaman, dengan jumlah tanaman sampel sebanyak 3 tanaman per plot. Jumlah tanaman sampel dari seluruh unit percobaan adalah 81tanaman.

\section{Persiapan dan Pelaksanaan Percobaan}

Sampel tanah dari lokasi penelitian dikeringanginkan dan diayak dengan ayakan berdiameter $2,0 \mathrm{~mm}$, selanjutnya dianalisis beberapa sifat-sifat kimia : Corganik ; N-total (\%); P-tersedia (ppm); Ktukar (me/100 g).

Benih yang digunakan adalah benih jagung varietas Hibrida-Pioneer yang telah disterilkan dengan cara merendam benih selama 5 menit dalam alkohol $70 \%$ untuk menghilangkan jamur yang ada pada benih.

Lahan yang akan digunakan sebelumnya dibersihkan dari gulma, kemudian dicangkul untuk menggemburkan tanah. Selanjutnya dibuat plot sebanyak 27 dengan ukuran $100 \mathrm{~cm} \mathrm{x}$ $150 \mathrm{~cm}$ per plot dengan jarak $50 \mathrm{~cm}$ sedangkan antar ulangannya $50 \mathrm{~cm}$. Lahan kemudian diberi pupuk urea, SP-36 dan $\mathrm{KCl}$ sebagai pupuk dasar, pada waktu tujuh hari sebelum tanam. Dibuat lubang tanam, kemudian benih jagung ditanam sebanyak dua benih pada setiap lubang tanam. Setelah tujuh hari penanaman maka diberikan mikoriza dicampur dengan pupuk kompos sesuai perlakuan, dan sekaligus dilakukan penjarangan. Penyiraman dilakukan setiap hari untuk mempertahankan kondisi kapasitas lapang.

Parameter yang diamati adalah pertumbuhan tanaman yang meliputi tinggi tanaman, diameter batang, berat berangkasan kering tanaman bagian atas dan akar, dengan cara mengeringkan tanaman dan akar di dalam oven pada temperatur $60-65{ }^{\circ} \mathrm{C}$ selama $24-48$ jam sampai mencapai berat konstan, kadar $\mathrm{P}$ dalam jaringan tanaman, parameter produksi diukur pada waktu panen : bobot kering 100 butir dan jumlah baris per tongkol.

\section{Analisis data}

Data hasil pengamatan dianalisis dengan analisis sidik ragam pada taraf nyata 5 persen dan jika ada beda nyata antar rerata parameter yang diuji dilakukan uji lanjut dengan Uji Jarak Berganda Duncan (Duncan's Multiple Range Test) pada taraf nyata 5 persen. 


\section{HASIL DAN PEMBAHASAN}

Hasil sidik ragam menunjukkan perlakuan inokulasi Mikoriza dan pemberian pupuk kompos berpengaruh nyata terhadap tinggi tanaman jagung pada umur 3, 4, 5 dan 6 mst. Interaksi antara kedua perlakuan berpengaruh tidak yata terhadap tinggi tanaman pada umur $3 \mathrm{mst}$, tetapi berpengaruh nyata pada umur 4,5 dan 6 mst. Rataan tinggi tanaman akibat inokulasi Mikoriza dan pemberian pupuk organik yang berbeda dapat dilihat pada Tabel 1.

Tabel 1. Tinggi Tanaman Jagung $(\mathrm{cm})$ dengan Perlakuan Inokulasi Mikoriza dan Pemberian Pupuk Kompos pada Umur 3, 4, 5 dan 6 Minggu Setelah Tanam

\begin{tabular}{ccccc}
\hline Perlakuan & \multicolumn{4}{c}{ Tinggi Tanaman $(\mathrm{cm})$} \\
\cline { 2 - 5 } & $3 \mathrm{MST}$ & $4 \mathrm{MST}$ & $5 \mathrm{MST}$ & $6 \mathrm{MST}$ \\
\hline $\mathrm{M}_{0}$ & $14,13 \mathrm{a}$ & $51,31 \mathrm{a}$ & $80,68 \mathrm{a}$ & $103,17 \mathrm{a}$ \\
$\mathrm{M}_{1}$ & $13,84 \mathrm{a}$ & $55,14 \mathrm{~b}$ & $84,52 \mathrm{a}$ & $111,67 \mathrm{~b}$ \\
$\mathrm{M}_{2}$ & $15,10 \mathrm{~b}$ & $57,84 \mathrm{~b}$ & $89,23 \mathrm{~b}$ & $116,10 \mathrm{c}$ \\
\hline $\mathrm{O}_{0}$ & $13,96 \mathrm{a}$ & $49,22 \mathrm{a}$ & $74,19 \mathrm{a}$ & $91,68 \mathrm{a}$ \\
$\mathrm{O}_{1}$ & $14,28 \mathrm{ab}$ & $56,31 \mathrm{~b}$ & $86,89 \mathrm{~b}$ & $97,22 \mathrm{~b}$ \\
$\mathrm{O}_{2}$ & $14,83 \mathrm{~b}$ & $58,77 \mathrm{~b}$ & $93,35 \mathrm{c}$ & $142,04 \mathrm{c}$ \\
\hline $\mathrm{M}_{0} \mathrm{O}_{0}$ & 13,56 & $42,40 \mathrm{a}$ & $66,31 \mathrm{a}$ & 86,97 \\
$\mathrm{M}_{0} \mathrm{O}_{1}$ & 14,16 & $54,88 \mathrm{c}$ & $88,12 \mathrm{~b}$ & 88,12 \\
$\mathrm{M}_{0} \mathrm{O}_{2}$ & 14,67 & $56,67 \mathrm{c}$ & $87,61 \mathrm{~b}$ & 134,42 \\
$\mathrm{M}_{1} \mathrm{O}_{0}$ & 13,27 & $49,70 \mathrm{~b}$ & $73,07 \mathrm{a}$ & 89,92 \\
$\mathrm{M}_{1} \mathrm{O}_{1}$ & 14,04 & $56,09 \mathrm{c}$ & $85,22 \mathrm{~b}$ & 101,34 \\
$\mathrm{M}_{1} \mathrm{O}_{2}$ & 14,20 & $59,64 \mathrm{c}$ & $95,27 \mathrm{c}$ & 143,73 \\
$\mathrm{M}_{2} \mathrm{O}_{0}$ & 15,04 & $55,56 \mathrm{c}$ & $83,18 \mathrm{~b}$ & 98,14 \\
$\mathrm{M}_{2} \mathrm{O}_{1}$ & 14,63 & $57,96 \mathrm{c}$ & $87,33 \mathrm{~b}$ & 102,19 \\
$\mathrm{M}_{2} \mathrm{O}_{2}$ & 15,63 & $60,00 \mathrm{c}$ & $97,18 \mathrm{c}$ & 147,98 \\
\hline
\end{tabular}

Keterangan: Angka rataan yang diikuti oleh huruf yang sama pada kolom yang sama tidak berbeda nyata pada taraf 5\% berdasarkan uji jarak Duncan.

Tabel 1 menunjukkan bahwa inokulasi mikoriza $\left(\mathrm{M}_{1}\right.$ dan $\left.\mathrm{M}_{2}\right)$ menghasilkan tanaman yang lebih tinggi dibandingkan dengan tanpa inokulasi mikoriza $\left(\mathrm{M}_{0}\right)$. Hasil penelitian menunjukkan bahwa pada umur 3 MST, pengaruh inokulan mikoriza belum nyata memiliki tinggi tanaman yang berbeda, tetapi pada umur 4 MST ada perbedaan yang nyata antara tinggi tanaman jagung yang diberi inokulan mikoriza dengan tanpa pemberian mikoriza. Pada umur 6 MST dapat diketahui bahwa tanaman jagung yang diberi inokulan mikoriza 10 g/tanaman memiliki tanaman yang lebih tinggi dibandingkan dengan inokulan 5 g/tanaman.

Hasil penelitian juga menunjukkan bahwa pada umur 3 MST, pemberian dosis pupuk kompos sebesar $100 \mathrm{~g} /$ tanaman nyata memiliki tanaman yang lebih tinggi dibandingkan dengan tanpa pemberian pupuk kompos, sedangkan pada umur 4, 5 dan 6 MST, pemberian dosis pupuk kompos sebesar 50g/tanaman nyata memiliki tanaman yang lebih tinggi dibandingkan dengan tanpa pemberian pupuk kompos.

Interaksi antara inokulasi Mikoriza dengan pupuk kompos berpengaruh nyata meningkatkan tinggi tanaman jagung pada umur 4, 5 dan 6 MST. Peningkatan tinggi tanaman jagung lebih baik pada kombinasi perlakuan inokulasi mikoriza $10 \mathrm{~g}$ dengan pemberian dosis pupuk kompos 100 g/tanaman.

Untuk melihat hubungan pemberian inokulasi Mikoriza dengan tinggi tanaman jagung pada berbagai dosis pupuk kompos dapat dilihat pada Gambar 1. 


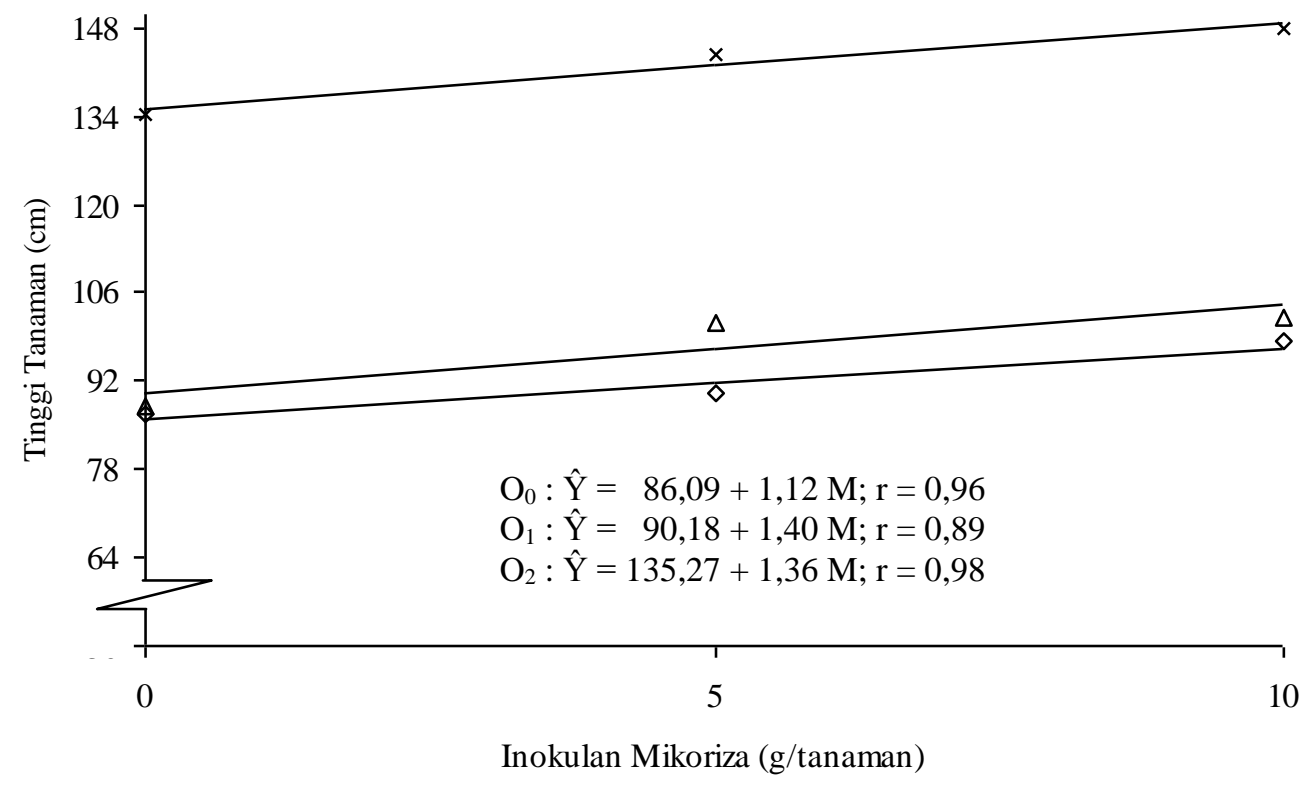

$\diamond \mathrm{O} 0 \Delta \mathrm{O} 1 \times \mathrm{O} 2$

Gambar 1. Pengaruh Inokulan Mikoriza terhadap Tinggi Tanaman Jagung pada Umur 6 Minggu Setelah Tanam pada Berbagai Dosis Pupuk Kompos

Gambar 1 menunjukkan bahwa inokulasi mikoriza akan semakin meningkatkan tinggi tanaman jagung. Peningkatan tinggi tanaman akan semakin cepat dengan pemberian pupuk kompos sebesar 100 g/tanaman.

Untuk melihat hubungan dosis pupuk kompos dengan tinggi tanaman jagung pada berbagai inokulasi Mikoriza dapat dilihat pada Gambar 2.

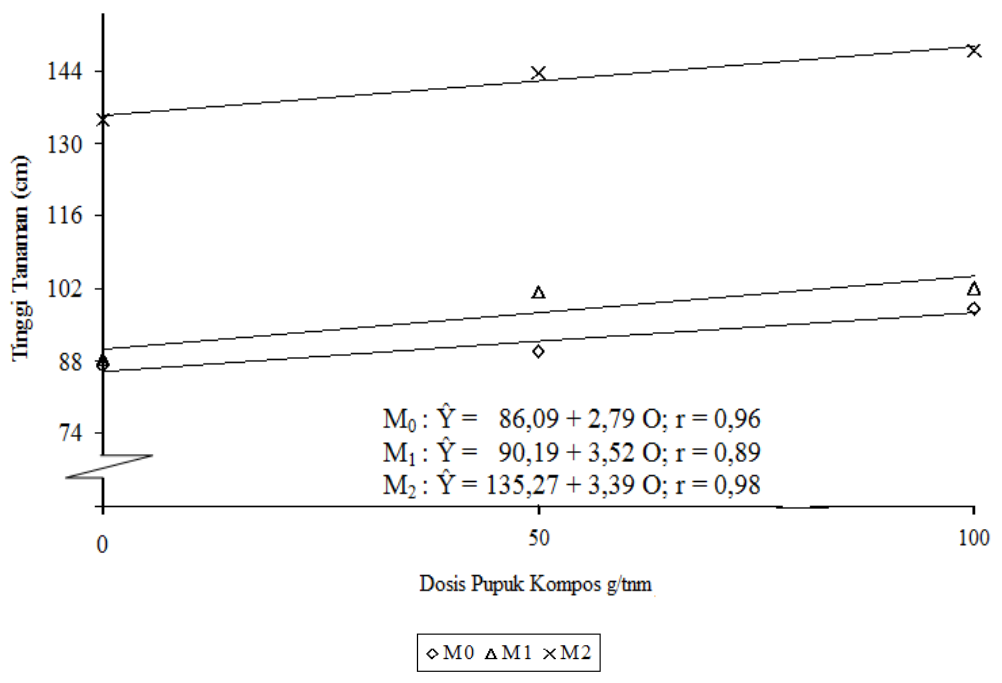

Gambar 2. Pengaruh Pupuk Organik terhadap Tinggi Tanaman Jagung pada Umur 6 Minggu Setelah Tanam pada Berbagai Inokulasi Mikoriza 
Gambar 2 menunjukkan bahwa dosis pupuk organik yang semakin meningkat, akan semakin meningkatkan tinggi tanaman jagung. Peningkatannya tinggi tanaman akan semakin cepat dengan inokulasi Mikoriza sebesar $10 \mathrm{~g} /$ tanaman. Tinggi tanaman pada tanaman yang diberi pupuk kompos yang dikombinasikan dengan inokulasi mikoriza $10 \mathrm{~g} /$ tanaman dua kali lipat lebih tinggi dibandingkan inokulasi mikoriza $5 \mathrm{~g} /$ tanaman.

\section{Diameter Batang}

Hasil sidik ragam menunjukkan perlakuan inokulasi Mikoriza berpengaruh

Tabel 2. Diameter Batang $(\mathrm{cm})$ dengan Perlakuan Inokulasi Mikoriza dan Pemberian Pupuk Kompos pada Umur 3, 4, 5 dan 5 Minggu Setelah Tanam nyata terhadap diameter batang tanaman jagung pada umur 3, 4, 5 dan 6 mst. Perlakuan pemberian pupuk kompos berpengaruh tidak nyata terhadap diameter batang pada umur 3 mst, tetapi berpengaruh nyata pada umur 4,5 , dan 6 mst. Interaksi antara kedua perlakuan berpengaruh tidak yata terhadap tinggi tanaman pada umur 3, 4 dan 5 mst, tetapi berpengaruh nyata pada umur 6 mst. Rataan diameter batang tanaman akibat inokulasi Mikoriza dan pemberian pupuk kompos yang berbeda dapat dilihat pada Tabel 2.

\begin{tabular}{ccccc}
\hline Perlakuan & \multicolumn{4}{c}{ Diameter Batang $(\mathrm{cm})$} \\
\cline { 2 - 5 } & $3 \mathrm{MST}$ & $4 \mathrm{MST}$ & $5 \mathrm{MST}$ & $6 \mathrm{MST}$ \\
\hline $\mathrm{M}_{0}$ & $0,17 \mathrm{a}$ & $0,50 \mathrm{a}$ & $1,41 \mathrm{a}$ & $1,79 \mathrm{a}$ \\
$\mathrm{M}_{1}$ & $0,16 \mathrm{a}$ & $0,58 \mathrm{~b}$ & $1,48 \mathrm{a}$ & $1,93 \mathrm{~b}$ \\
$\mathrm{M}_{2}$ & $0,21 \mathrm{~b}$ & $0,61 \mathrm{~b}$ & $1,60 \mathrm{~b}$ & $1,96 \mathrm{~b}$ \\
\hline $\mathrm{O}_{0}$ & 0,19 & $0,47 \mathrm{a}$ & $1,19 \mathrm{a}$ & $1,87 \mathrm{~b}$ \\
$\mathrm{O}_{1}$ & 0,18 & $0,59 \mathrm{~b}$ & $1,56 \mathrm{~b}$ & $1,73 \mathrm{a}$ \\
$\mathrm{O}_{2}$ & 0,17 & $0,63 \mathrm{~b}$ & $1,75 \mathrm{c}$ & $2,08 \mathrm{c}$ \\
\hline $\mathrm{M}_{0} \mathrm{O}_{0}$ & 0,19 & 0,39 & 1,04 & $1,47 \mathrm{a}$ \\
$\mathrm{M}_{0} \mathrm{O}_{1}$ & 0,16 & 0,53 & 1,57 & $1,80 \mathrm{c}$ \\
$\mathrm{M}_{0} \mathrm{O}_{2}$ & 0,16 & 0,59 & 1,62 & $2,09 \mathrm{~d}$ \\
$\mathrm{M}_{1} \mathrm{O}_{0}$ & 0,16 & 0,49 & 1,12 & $1,64 \mathrm{~b}$ \\
$\mathrm{M}_{1} \mathrm{O}_{1}$ & 0,18 & 0,59 & 1,53 & $1,83 \mathrm{c}$ \\
$\mathrm{M}_{1} \mathrm{O}_{2}$ & 0,16 & 0,66 & 1,79 & $2,32 \mathrm{e}$ \\
$\mathrm{M}_{2} \mathrm{O}_{0}$ & 0,21 & 0,54 & 1,39 & $2,49 \mathrm{f}$ \\
$\mathrm{M}_{2} \mathrm{O}_{1}$ & 0,20 & 0,66 & 1,57 & $1,57 \mathrm{ab}$ \\
$\mathrm{M}_{2} \mathrm{O}_{2}$ & 0,21 & 0,63 & 1,83 & $1,83 \mathrm{c}$ \\
\hline
\end{tabular}

Keterangan: Angka rataan yang diikuti oleh huruf yang sama pada kolom yang sama tidak berbeda nyata pada taraf $5 \%$ berdasarkan uji jarak Duncan.

Tabel 2 menunjukkan bahwa inokulasi mikoriza $\left(\mathrm{M}_{1}\right.$ dan $\left.\mathrm{M}_{2}\right)$ menghasilkan diameter batang tanaman yang lebih besar dibandingkan dengan tanpa inokulasi mikoriza $\left(\mathrm{M}_{0}\right)$. Hasil penelitian menunjukkan bahwa pengaruh inokulasi mikoriza memiliki perbedaan yang nyata antara diameter batang tanaman jagung yang diberi inokulan mikoriza dengan tanpa inokulasi mikoriza. Pada umur 3 dan 5 MST dapat diketahui bahwa 
dibandingkan dengan tanpa pemberian pupuk kompos.

Interaksi antara inokulasi Mikoriza dengan pupuk kompos berpengaruh nyata meningkatkan diameter batang tanaman jagung pada umur 6 MST. Peningkatan diameter batang tinggi tanaman jagung lebih baik pada kombinasi perlakuan inokulan mikoriza $10 \mathrm{~g}$ dengan pemberian dosis pupuk kompos $100 \mathrm{~g} /$ tanaman.

Untuk melihat hubungan inokulasi Mikoriza dengan diameter batang tanaman jagung pada berbagai dosis pupuk kompos dapat dilihat pada Gambar 3.

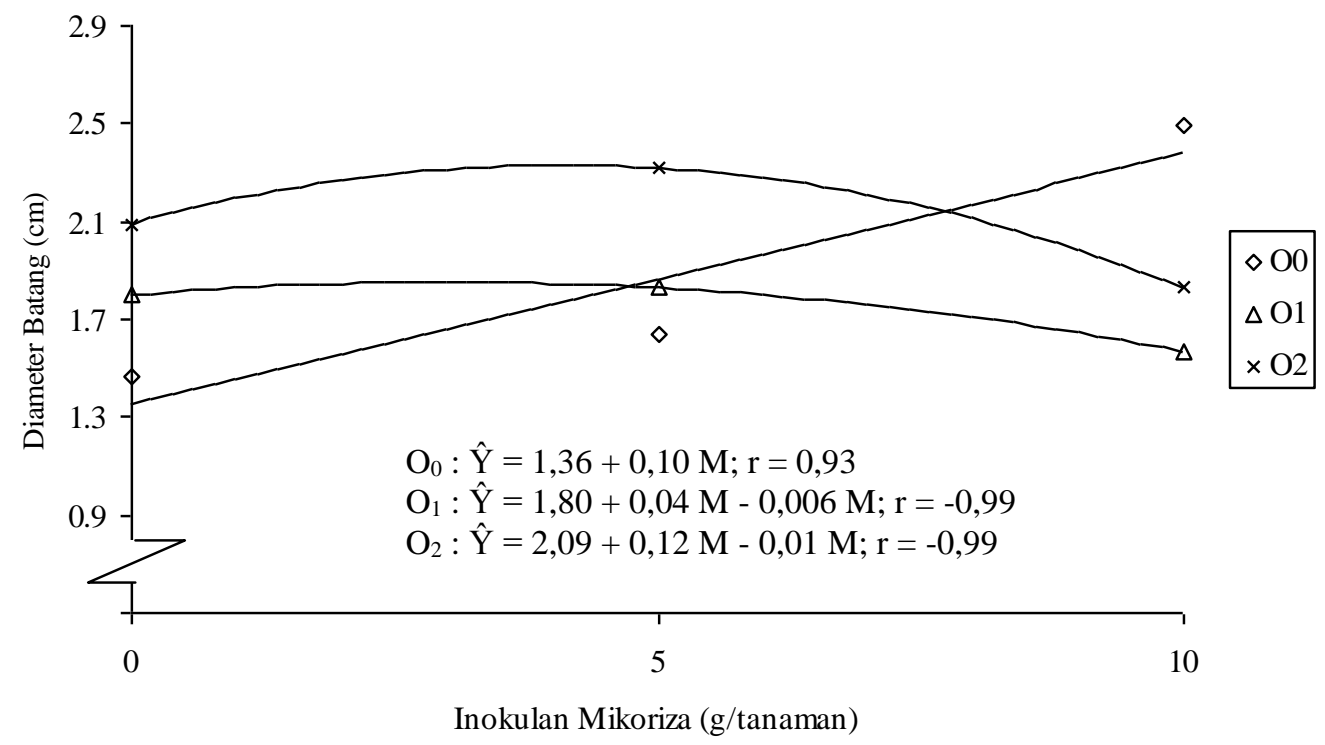

Gambar 3. Pengaruh Inokulan Mikoriza terhadap Diameter Batang Tanaman Jagung pada Umur 6 Minggu Setelah Tanam pada Berbagai Dosis Pupuk Kompos

Gambar 3 menunjukkan bahwa pada inokulasi Mikoriza tanpa disertai pemberian pupuk organik, pertumbuhan diameter batang berlangsung secara linier. Sedangkan jika inokulasi Mikoriza dikombinasikan dengan pemberian pupuk kompos maka diperoleh takaran inokulan mikoriza yang optimal untuk pertumbuhan diameter batang tanaman jagung.

Untuk melihat hubungan dosis pupuk organik dengan diameter batang tanaman jagung pada berbagai inokulasi Mikoriza dapat dilihat pada Gambar 4. 


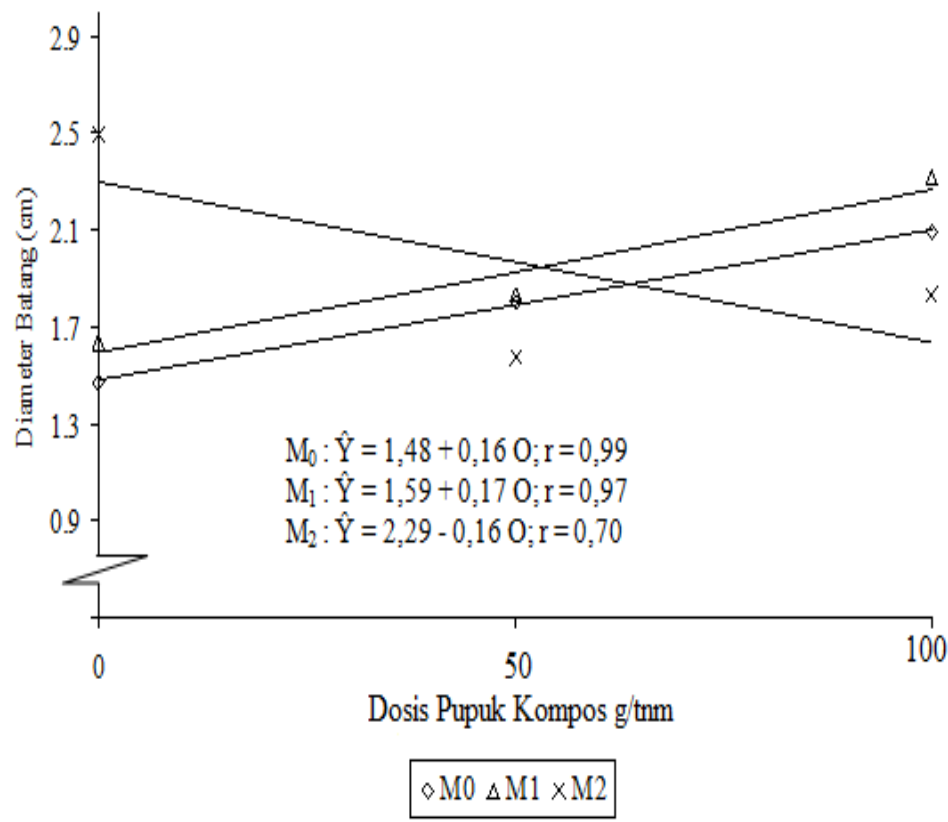

Gambar 4. Pengaruh Pupuk Kompos terhadap Diameter Batang Tanaman Jagung pada Umur 6 Minggu Setelah Tanam pada Berbagai Inokulasi Mikoriza

Gambar 4 menunjukkan bahwa pada kombinasi perlakuan inokulasi Mikoriza $10 \mathrm{~g} /$ tanaman dengan pemberian

\subsubsection{Kadar $P$ dalam jarinan tanaman}

Untuk mengetahui kadar P dalam jaringan tanaman dilakukan analisis di dosis pupuk kompos dapat menekan pertumbuhan diameter batang tanaman jagung.

laboratorium. Dari hasil analisis kadar P diperoleh hasil seperti pada Tabel 3. Tabel 3. Hasil Analisis P-total pada Tanaman Jagung pada Umur 50 Hari Setelah Tanam

\begin{tabular}{cc}
\hline Perlakuan & $\begin{array}{c}\text { Kadar P jaringan Tanaman } \\
(\%)\end{array}$ \\
\hline $\mathrm{M}_{0} \mathrm{O}_{0}$ & 0,25 \\
$\mathrm{M}_{0} \mathrm{O}_{1}$ & 0,35 \\
$\mathrm{M}_{0} \mathrm{O}_{2}$ & 0,27 \\
$\mathrm{M}_{1} \mathrm{O}_{0}$ & 0,44 \\
$\mathrm{M}_{1} \mathrm{O}_{1}$ & 0,48 \\
$\mathrm{M}_{1} \mathrm{O}_{2}$ & 0,54 \\
$\mathrm{M}_{2} \mathrm{O}_{0}$ & 0,44 \\
$\mathrm{M}_{2} \mathrm{O}_{1}$ & 0,60 \\
$\mathrm{M}_{2} \mathrm{O}_{2}$ & 0,43 \\
\hline
\end{tabular}

Dari Tabel 3 dapat dilihat bahwa kadar P tertinggi dalam jaringan tanaman jagung terdapat kombinasi perlakuan $\mathrm{M}_{2} \mathrm{O}_{1}$ sebesar $0,60 \%$, sedangkan terendah pada kombinasi perlakuan $\mathrm{M}_{0} \mathrm{O}_{0}$ sebesar $0,25 \%$.

Hasil penelitian menunjukkan bahwa pada inokulasi Mikoriza 5 g/tanaman akan mengalami peningkatan kadar $\mathrm{P}$ pada jaringan tanaman jika dilakukan pemupukan dengan pupuk kompos hingga 100 g/tanaman. Sedangkan pada tanpa inokulasi Mikoriza atau dengan inokulasi Mikoriza sebesar 10 g/tanaman, kadar P pada jaringan tanaman 
meningkat. Meningkatnya kadar P pada jaringan tanaman dengan adanya inokulasi mikoriza sebesar $10 \mathrm{~g} /$ tanaman dan dosisi pupuk organik sebesar $50 \mathrm{~g} /$ tanaman, disebabkan oleh adanya sumbangan langsung dari $\mathrm{P}$ yang terkandung di dalam pupuk organik yang ditambahkan, juga karena terjadinya pengaruh tidak langsung bahan organik terhadap P yang ada dalam kompleks jerapan tanah. Pemberian inokulan mikoriza meningkatkaan serapan $P$ oleh tanaman jagung. Menurut Bethlenfalvey et.al (1985), pengaruh yang menguntungkan dari mikoriza terhadap pertumbuhan tanaman sering dihubungkan dengan peningkatan serapan hara yang tidak mobil, terutama fosfor $(\mathrm{P})$. Peranan mikoriza adalah membantu akar tanaman melalui hifa yang terbentuk untuk dapat menjangkau hara $\mathrm{P}$ bahakan pada jarak yang jauh untuk diserap tanaman (Setiadi 2001). Selanjutnya pemberian dosis pupuk organik di atas $50 \mathrm{~g} /$ tanaman akan me urunkan kadar $\mathrm{P}$ pada jaringan tanaman. Menurunnya serapan $\mathrm{P}$ tanaman jagung boleh jadi akibat tingginya konsentrasi hara dalam larutan tanah yang melebihi ambang batas toleransi tanaman dalam bermetabolisme. Apabila konsentrasi ion di dalam tanah terlalu tinggi sedangkan toleransi tanaman untuk penyerapan tersebut sudah tidaak mencukupi lagi maka sel dalam jaringan tanaman (terutama akar) akan pecah. Ini menyebabkan tanaman menjadi rusak. Bila sistem perakaran rusak, maka pertumbuhan akar tanaman dan pembentukan bulu akar juga terhambat sehingga translokasi hara ke organ tanaman lain seperti daun, buah dan biji ikut terhambat.

\subsubsection{Berat Kering Brangkasan}

Untuk mengetahui berat kering brangkasan tanaman dilakukan analisis dengan cara mengeringkan tanaman dan akar di dalam oven pada temperatur $60-$ $65{ }^{\circ} \mathrm{C}$ selama $24-48$ jam sampai mencapai berat konstan. Dari hasil analisis berat kering brangkasan diperoleh hasil seperti pada Tabel 4.

Tabel 4. Hasil Analisis Berat Kering Brangkasan Tanaman Jagung pada Umur 50 Hari Setelah Tanam

\begin{tabular}{cc}
\hline Perlakuan & $\begin{array}{c}\text { Berat Kering Brangkasan } \\
(\mathrm{g} / \text { tanaman })\end{array}$ \\
\hline $\mathrm{M}_{0} \mathrm{O}_{0}$ & 55,27 \\
$\mathrm{M}_{0} \mathrm{O}_{1}$ & 39,98 \\
$\mathrm{M}_{0} \mathrm{O}_{2}$ & 56,67 \\
$\mathrm{M}_{1} \mathrm{O}_{0}$ & 23,36 \\
$\mathrm{M}_{1} \mathrm{O}_{1}$ & 23,78 \\
$\mathrm{M}_{1} \mathrm{O}_{2}$ & 56,57 \\
$\mathrm{M}_{2} \mathrm{O}_{0}$ & 30,42 \\
$\mathrm{M}_{2} \mathrm{O}_{1}$ & 8,17 \\
$\mathrm{M}_{2} \mathrm{O}_{2}$ & 27,18 \\
\hline
\end{tabular}

Dari Tabel 4 dapat dilihat bahwa berat kering brangkasan tertinggi terdapat kombinasi perlakuan $\mathrm{M}_{0} \mathrm{O}_{2}$ sebesar 56,67 g/tanaman, sedangkan terendah pada kombinasi perlakuan $\mathrm{M}_{2} \mathrm{O}_{1}$ sebesar 8,17 $\mathrm{g} /$ tanaman.

Hasil penelitian menunjukkan bahwa berat kering brangkasan lebih tinggi pada tanaman yang tidak diberi inokulan Mikoriza. Berat kering brangkasan semakin menurun dengan inokulasi Mikoriza yang semakin meningkat. 


\section{SIMPULAN DAN SARAN}

Atas dasar hasil dan analisis hasil serta pembahasan yang terbatas pada ruang lingkup penelitian ini, maka dapat disimpulkan bahwa inokulasi mikoriza sebesar $10 \mathrm{~g} /$ tanaman dan pupuk organik sebesar $100 \mathrm{~g} /$ tanaman memberikan kontribusi yang nyata terhadap pertumbuhan tanaman jagung meliputi tinggi tanaman dan diameter batang, sedangkan inokulasi mikoriza sebesar 10 g/tanaman dan dosis pupuk kompos sebesar $50 \mathrm{~g} /$ tanaman dapat meningkatkan serapan $\mathrm{P}$ oleh tanaman jagung. Dengan demikian dapat disimpulkan bahwa kontribusi pemberian mikoriza dan pupuk kompos dapat memacu pertumbuhan tanaman jagung dengan cara meningkatkan P-tersedia dan mengefektifkan penyerapan $\mathrm{P}$ sehingga penggunaan pupuk $\mathrm{P}$ dapat lebih efisien.

Melihat kontribusi yang diberikan oleh mikoriza dan pupuk kompos ini, maka disarankan agar pemanfaatan mikoriza dan pupuk kompos dapat dijadikan suatu alternatif untuk mendapat pertumbuhan dan hasil tanaman yang lebih baik, terutama dalam kaitannya untuk mengoptimalisasikan pemanfaatan lahanlahan yang berkesuburan rendah, disamping dapat mengurangi beban pencemaran terhadap lingkungan karena tidak menggunakan bahan-bahan kimia.

\section{DAFTAR PUSTAKA}

Auge, R.M. and A.J.W. Stadola. 1990. An apparent Increase in Symplastic in Water Contributes to Greater Turgor in Mycorrhizal Roots of Droughted Rosa Plants. New Phytol. 115, 285-295.

Berta, G; A. Fusconi; A. Trotta and S. Scannerini. 1990. Morphogenetic modification Induced By the Mycorrhizal Fungus Glomus Strain E3 in the Root System of Allium porrum L. New Phytol. 114, 207215.
Bethlenfalvay, G.J., M.S. Brown and R.S. Pacosvsky. 1982. Parasitic Mutualistic Assosiation Between a Mycorrhizal Fungus and Soybean. Development of the Host Plants Phytopathology. 72 : $889-893$.

Bethlenfalvay, G.J., M.G. Reyes-Solis, S.B. Camel and R. Ferrera-Cerrato. 1991. Nutrient transfer Between The Root Zones of Soybean and Maize plants Connected By a Common Mycorrhizal Mycelium. Physiol. Plant. 82, 423-432.

Bolan, N.S. 1991. A Critical Review of The Role of Mycorrhizal Fungi in The Uptake of Pfosphorus by Plants. Plant Soil. 134, 189-207.

Berita Resmi Statistik No. 20/03/ Th. XVI, 1 Maret 2013

Chang, D.C.N. 1992. Studies and Prospect of Horticultural VesicularArbuscular Mycorrhizae. In Taiwan. Sci. Agric. 40, 45-52.

Chang, D.C.N., 1994. What is The Potential for Mangement of Vesicular-Arbuscular Mycorrhizae in Hoticulture? In Management of Mycorrhizas in Agriculture, Horticulture and Forestry. Eds. A.D. Robson, L.K. Abbott and N. Malajczuk. Kluwer Academic Publishers. 187 - 190 pp. The Netherland.

Cottenie, A., M. Verloo, L. Kiekens., G. Velghe and R. Camerlynck. 1982. Chemical Analysis of Plants and Soil. Laboratory of Analytical and Agrochemistry. State University Ghent. Belgium.

Darmawijaya, M.I. 1992. Klasifikasi Tanah. Dasar Teori Bagi Peneliti Tanah dan Pelaksanaan Pertanian di Indonesia. Fakultas Pertanian. Universitas Gadjah Mada. Yogyakarta.

Jakobsen, I. And L. Rosendahl. 1990. Carbon Flow Into Soil and External Hyphae From Roots of Mycorrhizal Cucumber Plants. New Phytol. 115, 77-83. 
Kartini, N.I. 2000. Peranan Pupuk Organik Kascing dan Pupuk Hayati Mikoriza Dalam Menunjang Pertanaian Organik Yang Berwawasan Lingkungan. Fakultas Pertanian. Udayana. Bali.

Lakibatn, B. 1995. Fisiologi Pertumbuhan dan Perkembangan Tanaman. PT. Raja Grafindo Persada. Jakarta.

Lambers, H., F.S. Chapin and T.L. Pons. 1998. Plant Fisiological Ecological. Springer-Verlag. New York.

Marschner, H. 2002. Mineral Nutrition of Higher Plants. Fifth printing. Academic Press. London. UK.

Murbandono, HS.L. 2001. Membuat Kompos. Edisi Revisi. Penebar Swadaya. Jakarta.

Narta, I. K., 2002. Pengaruh Penggunaan Pupuk Hayati Biofer 2000-N dan Pupuk Organik Kascing Terhadap Pertumbuhan Bibit Kakao (Theobroma cacao. L). Program Studi Magister Pertanian Lahan Kering. Program Pasca Sarjana, Universitas Udayana. Denpasar.

Niswati, A., S.G. Nugroho, M. Utomo dan Suryadi, 1996. Pemanfaatan Mikoriza Vesikular Arbuskular Untuk Mengatasi Pertumbuhan Jagung Akibat Cekaman Kekeringan. Junal Ilmu Tanah. Fakultas Pertanian. Universitas Lampung. No.3 Lampung.

Perrin, R. 1990. Interactions Between Mycorrhizae and Deseases Caused by Soil-born Fungi. Soil Use Manag. 6, 189-195.

Prawirowardoyo, S., A. Rosmarkam, D. Shiddieq, Hidayat, MS. Dan Ma'shum, M. 1982. Prosedur Analisa Kimia Tanah. Departemen Ilmu Tanah. Fakultas Pertanian.Universitas Gadjah Mada. Yogyakarta.

Raharjo, B.W.S. 1990. Pedoman Praktikum VA Mikoriza. Kerjasama antara PAU IPB dengan PAU Bioteknologi UGM. Yogyakarta.
Sieverding, E., 1991. Vesicular-Arbuscular Mycorrhiza Management in Tropical Agrosystem. Technical Cooperation Federal Republic of Germany.

Tisdale, S., W. Nelson, and J.D. Beaton, 1985. Soil Fertility and Fertilizers. Fourth Edition. Collier Mc Millan Publishing Co. Inc. New York. 754 $\mathrm{h}$.

Wraith, J.M. and C. K. Wright, 1998. Soil Water and Root Growth. Proceeding of the Colloquium. In Soil Environment and Root Growth. American Society for Horticultural Science. Alexandria, VA. 33(6), 951-959. 